\title{
ANALISIS DAYA SAING APEL JAWA TIMUR (Studi Kasus Apel Batu, Nongkojajar dan Poncokusumo)
}

\author{
East java application competitive analysis \\ (case study of apples batu, nongkojajar and poncokusumo) \\ Novi Itsna Hidayati ${ }^{1)}$, Teguh Sarwo Aji ${ }^{2)}$ \\ ${ }^{1}$ Dosen Fakultas Pertanian Universitas Yudharta Pasuruan \\ Email: teguh@yudharta.ac.id
}

\begin{abstract}
ABSTRAK
Apel yang terkenal di Jawa Timur adalah apel yang berasal dari Malang (Batu dan Poncokusumo) dan Kabupaten Pasuruan (Nongkojajar). Tujuan penelitian ini adalah (a) menganalisa daya saing komoditas apel di Jawa Timur berdasarkan keunggulan komparatif dan keunggulan kompetitif dibandingkan dengan apel impor, (b) menganalisa hasil sensitivitas hasil analisa keunggulan komparatif dan keunggulan kompetitif tersebut akibat adanya perubahan input dan output. Metode analisis yang digunakan adalah analisis keunggulan komparatif, analisis keunggulan kempetitif, analisis Policy Analysis Matrix (PAM) dan analisis sensirivitas digunakan untuk menganalisis dampak kebijakan harga maupun kebijakan investasi pertanian. Hasil analisis PAM dapat menunjukkan pengaruh individual maupun kolektif dari kebijakan harga dan kebijakan faktor domestik. Hasil penelitian menunjukkan bahwa Analisa rata-rata nilai DRCR sebesar 0,69 dan nilai rata-rata PCR sebesar 0,49. Dengan demikian analisa keunggulan kompetitif lebih besar dari analisa keunggulan komparatif, sehingga usahatani apel Jawa Timur masih mempunyai daya saing baik di pasar dalam negeri mapun pasar luar negeri. Analisis sensitivitas dengan naiknya harga bibit sebesar 10\%, kenaikan upah tenaga kerja sebesar $10 \%$, harga pupuk sebesar $10 \%$ dan penurunan output sebesar $10 \%$ menyebabkan perubahan DRCR dan PCR, akan tetapi nilainya masih dibawah satu. Hal ini berarti bahwa usahatani apel di Jawa Timur masih layak untuk diusahakan.
\end{abstract}

Kata kunci : daya saing, apel, jawa timur

\begin{abstract}
The famous apples in East Java are apples from Malang (Batu and Poncokusumo) and Pasuruan Regency (Nongkojajar). The purpose of this study is (a) to analyze the competitiveness of apple commodities in East Java based on comparative advantage and competitive advantage compared to apple imports, $(b)$ analyze the sensitivity results of the analysis of comparative advantage and competitive advantage due to changes in inputs and outputs. The analytical method used is the analysis of comparative advantage, analysis of competitive advantage, Policy Analysis Matrix (PAM) analysis and sensiriveny analysis used to analyze the impact of price policies and agricultural investment policies. The results of the PAM analysis can show both individual and collective effects of price policies and domestic factor policies. The results showed that the analysis of the average DRCR value was 0.69 and the average value of PCR was 0.49. Thus the analysis of competitive advantage is greater than the analysis of comparative advantage, so that East Java apple farming still has good competitiveness in the domestic market and foreign markets. Sensitivity analysis with an increase in seed prices by $10 \%$, an increase in labor wages by $10 \%$, fertilizer prices by $10 \%$ and a decrease in output by 10\% causing changes in DRCR and PCR, but the value is still below one. This means that apple farming in East Java is still feasible.
\end{abstract}

Keywords: competitiveness, apple, east java 


\section{PENDAHULUAN}

Buah-buahan merupakan salah satu komoditas hortikultura yang masih sangat prospektif untuk dikembangkan. Hal ini didukung oleh jumlah permintaan konsumsi buah-buahan Indonesia yang terus meningkat sebesar $12-15 \%$ per tahun. Menurut Bina Produksi Tanaman Pangan dan Hortikultura dalam Ardiansyah (1997) permintaan buahbuahan pada tahun 2000-2005 telah mengalami peningkatan sebessar $6,5 \%$, dan untuk tahun 2010-2015 diproyeksikan akan mengalami peningkatan sebesar $6,9 \%$. Pertumbuhan permintaan tersebut akan terus meningkat sejalan dengan pertambahan jumlah penduduk, peningkatan pendapatan dan pendidikan yang mendorong kesadaran gizi masyarakat.

Era perdagangan bebas yang ditandai dengan semakin terbukanya perdagangan komoditas (produk) antar negara merupakan peluang sekaligus ancaman bagi pengembangan produk pertanian di Indonesia, termasuk didalamnya komoditas hortikultura. Artinya produk hortikultura Indonesia berpeluang masuk pasar dunia, namun di sisi lain peluang bagi produk luar negeri memasuki pasar domestik Indonesia.
Produk - produk hortikultura dari luar negeri tersebut merupakan pesaing bagi produk-produk hortikultura Indonesia. Di samping itu adanya perdagangan bebas menjadikan produsen produk-produk hortikultura Indonesia tidak bisa menikmati proteksi berlebihan yang selama ini diberikan oleh Pemerintah melalui pengaturan tarif bea masuk, pajak dan subsidi karena proteksi yang berlebihan dilarang dalam aturan perdagangan bebas dunia seperti yang diatur oleh WTO (World Trade Organization).

Salah satu komoditi hortikultura yang diperdagangkan secara internasional dan regional adalah Apel. Jawa Timur merupakan salah satu sentra produksi terbesar buah apel di Indonesia yang mulai tumbuh berkembang pada tahun 1970-an dan pada puncak perkembangannya pada tahun 1980-an sampai dengan pertengahan tahun 1990-an di Batu, Poncokusumo Malang dan Nongko Jajar Pasuruan (Sudaryanto et all, 1992). Impor buah apel Indonesia pada tahun 2005 sebanyak 74.019 ton senilai US\$ 32.005.000 atau setara dengan Rp.288.045.000.000,- $\quad(1$ US\$ = Rp.9000,-) jumlah tersebut diperkirakan akan terus meningkat $3,9 \%$ per tahun 
hingga tahun 2010. Berdasarkan data dari Deperindag Jawa Timur volume impor apel di Jawa Timur pada tahun 2003 dan 2004 adalah 11.723,107 ton dan $19.788,258$ ton mengalami peningkatan $68,80 \%$ sedangkan volume ekspornya nol dari tahun 2000. Membanjirnya buah apel impor ini seiring dengan melesunya kegiatan agribisnis apel di dalam negeri yang berlangsung pada tahun 2000-an. Hal ini ditunjukkan oleh kondisi pertanaman apel di lahan petani yang kurang terpelihara, menurunnya produksi, mutu buah, harga sarana produksi yang tidak terjangkau dan harga buah apel yang relatif murah. Langkah-langkah subtitusi impor perlu dilakukan untuk menghemat devisa (Suhariyanto, 2011) hal ini menunjukkan bahwa apel lokal kita masih kalah bersaing dengan apel-apel impor.

Terhambatnya ekspor disebabkan karena kondisi politik keamanan yang berkembang di Indonesia tidak menentu yang mengakibatkan naiknya harga input, selain dicabutnya subsidi pupuk dan obatobatan. Kondisi demikian mengakibatkan berkurangnya kualitas dan kuantitas produksi apel. Penyebab lain adalah berkaitan dengan kebijakan standarisasi pertanian yang melalui proses panjang diantaranya adalah pemberlakuan standar, akreditasi, sertifikasi serta pembinaan dan pengawasan penerapan standart. Kebijakan ekspor impor barang juga mempengaruhi karena barang-barang yang diekspor harus memenuhi proses standarisasi di bidang pertanian. Selain itu penerapan SK Menteri Keuangan No.378/KMK.01/1996 mengenai penurunan tarif impor juga mempengaruhi persaingan dalam perdagangan, karena dengan rendahnya tarif impor maka produk luar negeri khususnya apel banyak yang masuk ke wilayah kita sehingga harga apel akan menjadi lebih murah, sehingga pendapatan produsen domestik/petani menurun.

Oleh karena itu produk pertanian / hortikultura Indonesia dituntut untuk dapat meningkatkan daya saingnya agar mampu bersaing dengan produk sejenis dari luar negeri sehingga produk pertanian Indonesia dapat unggul di pasar domestik maupun di pasar internasional. Dalam menciptakan daya saing produk-produk pertanian Indonesia tersebut bisa diawali dengan mengembangkan produk-produk pertanian yang memiliki keunggulan komparatif (comparative advantage).

Sentra produksi apel di Jawa Timur telah dikenal masyarakat seperti apel Batu, apel Poncokusumo dan Apel Nongkojajar. Dari ketiga sentra prosuksi apel tersebut yang telah dikaji oleh 
beberapa peneliti adalah apel Batu dan apel Poncokusumo. Oleh karena itu diperlukan kajian lanjutan tentang daya saing dari ketiga sentra produksi apel untuk mengetahui sentra produksi apel yang memiliki daya saing paling tinggi.

\section{TUJUAN PENELITIAN}

Tujuan dari penelitian ini adalah untuk:

a. Menganalisa daya saing komoditas apel di Jawa Timur berdasarkan keunggulan komparatif dan keunggulan kompetitif dibandingkan dengan apel impor.

b. Menganalisa hasil sensitivitas hasil analisa keunggulan komparatif dan keunggulan kompetitif tersebut akibat adanya perubahan input dan output.

\section{METODE PENELITIAN}

Penelitian ini dilaksanakan di Nongkojajar Kabupaten Pasuruan, Poncokusumo Kabupaten Malang dan Batu. Daerah ini dipilih karena ke tiga daerah tersebut merupan sentra produksi apel terbesar di Jawa Timur. Dengan dasar tersebut lokasi penelitian ditetapkan secara purposive sampling. Pengamatan dilakukan pada tiga lokasi yang berbeda. Teknik pengambilan sampel dilakukan secara purposive sampling pada tiap lokasi dengan menyebarkan kuisioner terhadap 30 responden di setiap lokasi penelitian. Pada penelitian ini digunakan 2 jenis sumber data yaitu :

a. Data primer

Data primer merupakan data yang diperoleh langsung dari lapangan yaitu dengan melakukan wawancara langsung dengan pihak - pihak terkait dalam hal ini kepala Desa, Ketua Kelompok Tani dan Para petani apel, serta beberapa lembaga terkait lainnya.

b. Data sekunder

Data sekunder diperoleh dengan mengumpulkan sumber tertulis atau dokumen dari Kantor Desa, Kecamatan, Dinas Pertanian, dan dari berbagai buku pustaka yang ada kaitan dengan penelitian ini.

\section{Teknik Analisis Data}

Analisis keunggulan komparatif agribisnis usahatani apel digunakan rumus sebagai berikut:

$$
\mathrm{DRCR}=\frac{D R C}{S E R}
$$

Dimana:

$$
\begin{aligned}
\text { DRCR = } & \text { rasio biaya sumberdaya } \\
& \text { domestic }(\%) \\
\mathrm{DRC}= & \text { biaya sumberdaya domestic } \\
& \text { yang digunakan }(\mathrm{Rp}) \\
\mathrm{SER}= & \text { Shadow exchange rate } \\
& (\mathrm{Rp} / \mathrm{US} \$)
\end{aligned}
$$


kriteria penilaian adalah:

1. DRCR > 1, berarti agribisnis usahatani apel tidak efisien secara ekonomik atau tidak mempunyai keunggulan komparatif.

2. DRCR $<1$, berarti agribisnis usahatani apel efisien dan secara ekonomi mempunyai keunggulan komparatif.

3. DRCR $=1$, berarti agribisnis usahatani apel dalam keseimbangan

Sedangkan analisis keunggulan kompetitif agribisnis usahatani apel menggunakan rumus sebagai berikut:

$$
\mathrm{PCR}=\frac{D R C}{N T R}
$$

Dimana:

PCR = rasio biaya sumberdaya domestic atau harga actual $(\%)$

DRC = biaya sumberdaya domestic berdasarkan harga aktual (Rp)
NTR $=$ nilai tengah rupiah (Rp/US\$)

kriteria penilaian adalah:

1. PCR $>1$, berarti agribisnis apel tidak efisien secara finansial atau tidak mempunyai keunggulan kompetitif.

2. PCR $<1$, berarti agribisnis apel efisien dan secara finansial mempunyai keunggulan kompetitif.

3. $\operatorname{PCR}=1$, berarti agribisnis apel dalam keseimbangan

\section{Policy Analysis Matrix (PAM)} digunakan untuk menganalisis dampak kebijakan harga maupun kebijakan investasi pertanian. Hasil analisis PAM dapat menunjukkan pengaruh individual maupun kolektif dari kebijakan harga dan kebijakan faktor domestik. Metode ini dapat di lihat pada tabel 3 di bawah ini:

Tabel 3. Policy Analysis Matrix (PAM)

\begin{tabular}{|l|c|c|c|c|}
\hline \multirow{2}{*}{ Penerimaan } & \multicolumn{2}{|c|}{ Biaya } & \multirow{2}{*}{ pendapatan } \\
\cline { 3 - 4 } & & Input tradable & Input domestic & \\
\hline Harga pasar & $\mathrm{A}$ & $\mathrm{B}$ & $\mathrm{C}$ & $\mathrm{D}$ \\
\hline Harga social & $\mathrm{E}$ & $\mathrm{F}$ & $\mathrm{G}$ & $\mathrm{H}$ \\
\hline Policy transfer & $\mathrm{I}$ & $\mathrm{J}$ & $\mathrm{K}$ & $\mathrm{L}$ \\
\hline
\end{tabular}

Sumber: Scott Pearson, 2005

Keterangan:

$\mathrm{A}=$ penerimaan individu, yaitu produksi dikalikan dengan harga pasar (Rp)
$\mathrm{B}=$ input tradable dikalikan dengan harga pasar (Rp)

$\mathrm{C}=$ input faktor domestik dikalikan dengan harga pasar (Rp) 
$\mathrm{D}=$ pendapatan individu, $(\mathrm{A}-(\mathrm{B}+\mathrm{C}))$ dikurangkan dari seluruh penerimaan. (Rp)

Biaya-biaya disini dibedakan menjadi dua

$\mathrm{E}=$ Penerimaan sosial, yaitu produksi yaitu biaya tetap dan biaya variable dikalikan dengan harga sosial (Rp) (lampiran ). Biaya pada usahatani apel

$\mathrm{F}=$ input tradable dikalikan dengan yang dihitung adalah : (1) biaya bibit; (2) sosial (Rp)

$\mathrm{G}=$ input faktor domestik dikalikan biaya tenaga kerja; (3) biaya pupuk; (4) dengan harga sosial $(\mathrm{Rp})$ biaya pestisida; (4) biaya penyusutan alat; (5) biaya sewa lahan serta biaya modal.

$\mathrm{H}=$ pendapatan sosial, $(\mathrm{E}-(\mathrm{F}+\mathrm{G}))$

\section{Analisis pendapatan finansial}

Pendapatan secara finansial

$\mathrm{I}=$ output transfer $(\mathrm{A}-\mathrm{E})$

merupakan selisih antara total penerimaan (Rp) (perkalian antara total produksi dengan

$\mathrm{J}=$ input $\quad$ transfer $\quad(\mathrm{B}$

F) harga yang berlaku) dengan total biaya (Rp) produksi yang dikeluarkan berdasarkan

$\mathrm{K}=$ factor domestik transfer $(\mathrm{C}-\mathrm{G})$ hal-hal yang terjadi sekarang ini. Dalam $(\mathrm{Rp})$ analisis financial penerimaan dihitung $\mathrm{L}=$ Net policy transfer $(\mathrm{D}-\mathrm{H})$ berdasarkan harga yang terjadi di pasar $(\mathrm{Rp})$

\section{HASIL DAN PEMBAHASAN}

Analisis Pendapatan Finansial dan usahatani apel di Poncokusumo, Ekonomik Usahatani Apel di Jawa Nongkojajar dan Batu Jawa Timur dapat Timur dilihat pada table 1. di bawah ini:

Pendapatan petani apel diperoleh dari total biaya yang dikeluarkan Tabel 1. Rata-rata pendapatan financial usahatani apel per hektar di Poncokusumo, Nongkojajar dan Batu Jawa Timur

\begin{tabular}{|l|l|r|r|r|}
\hline \multirow{2}{*}{ No } & \multicolumn{1}{|c|}{ Uraian } & \multicolumn{1}{c|}{ Poncokusumo } & \multicolumn{1}{c|}{ Nongkojajar } & \multicolumn{1}{c|}{ Batu } \\
\hline A & Biaya Produksi & & & \\
\hline & 1. Bibit & $6,000,000$ & $6,000,000$ & $6,000,000$ \\
\hline & 2. Tenaga Kerja & $15,461,600$ & $11,667,600$ & $14,088,375$ \\
\hline & 3. Pupuk & $17,933,300$ & $18,966,600$ & $17,818,500$ \\
\hline
\end{tabular}




\begin{tabular}{|l|l|r|r|r|} 
& 4. Pestisida & $9,567,300$ & $8,712,000$ & $8,898,093$ \\
\hline & 5. Sewa Lahan & $2,500,000$ & $2,500,000$ & $2,500,000$ \\
\hline & 6. Penyusutan Alat & 77,700 & 77,700 & 77,700 \\
\hline & $\begin{array}{l}\text { TOTAL BIAYA } \\
\text { PRODUKSI }\end{array}$ & $\mathbf{5 1 , 5 3 9 , 9 0 0}$ & $\mathbf{4 7 , 9 2 3 , 9 0 0}$ & $\mathbf{4 9 , 3 8 2 , 6 6 8}$ \\
\hline B & Biaya Pemasaran & & & $1,800,000$ \\
\hline & 1. Pengangkutan & $1,800,000$ & $1,800,000$ & $2,500,000$ \\
\hline & 2. Penanganan & $2,500,000$ & $2,300,000$ & $1,500,000$ \\
\hline & 3. Resiko & $1,500,000$ & $1,500,000$ & $5,800,000$ \\
\hline & TOTAL BIAYA & $5,800,000$ & $5,600,000$ & $\mathbf{5 5 , 1 8 2 , 6 6 8}$ \\
\hline & PEMASARAN & $\mathbf{5 7 , 3 3 9 , 9 0 0}$ & $\mathbf{5 3 , 5 2 3 , 9 0 0}$ & $\mathbf{1 1 2 , 8 0 0 , 0 0 0}$ \\
\hline & BIAYA TOTAL & $\mathbf{1 1 5 , 0 6 6 , 6 0 0}$ & $\mathbf{1 0 2 , 4 0 0 , 0 0 0}$ & $\mathbf{5 7 , 6 1 7 , 3 3 2}$ \\
\hline C & Penerimaan & $\mathbf{5 7 , 7 2 6 , 7 0 0}$ & $\mathbf{4 8 , 8 7 6 , 1 0 0}$ & \\
\hline D & Pendapatan & & & \\
\hline
\end{tabular}

Sumber: diolah dari data primer

Dari table tersebut diketahui bahwa secara financial pendapatan yang didapat rata-rata per hektar adalah sebesar 57.726 juta untuk daerah Poncokusumo, 48.876 juta untuk daerah Nongkojajar dan 57.617 juta untuk daerah Batu. Hal ini menunjukkan bahwa usahatani apel baik yang berasal dari Poncokusumo, Nongkojajar maupun batu secara financial menguntungkan bagi para petani sehingga usahatani tersebut layak untuk diusahakan.

\section{Analisis pendapatan ekonomik}

Pendapatan ekonomik merupakan selisih antara total penerimaan dengan total biaya produksi yang dikeluarkan, dalam hal ini semua komponennya baik input maupun output dinilai berdasarkan harga social atau harga bayangan. Penerimaan social usahatani apel adalah perkalian antara total produksi dengan harga bayangannya. Sedangkan biaya social usahatani apel adalah seluruh biaya yang dihitung berdasarkan harga bayangannya, baik secara tunai maupun yang diperhitungkannya. Pendapatan ekonomik merupakan pendapatan yang diperoleh apabila pasar diasumsikan berada dalam kondisi pasar persaingan sempurna. Pendapatan usahatani apel dapat dilihat pada table 2. di bawah ini:

Tabel 2. Rata-rata pendapatan ekonomik usahatani apel per hektar di Poncokusumo, Nongkojajar dan Batu Jawa Timur

\begin{tabular}{|l|l|r|r|r|}
\hline \multicolumn{1}{|c|}{ No } & \multicolumn{1}{|c|}{ Uraian } & Poncokusumo & \multicolumn{1}{c|}{ Nongkojajar } & \multicolumn{1}{c|}{ Batu } \\
\hline A & Biaya Produksi & & & \\
\hline & 1. Bibit & $5,275,000$ & $5,275,000$ & $5,275,000$ \\
\hline
\end{tabular}




\begin{tabular}{|l|l|r|r|r|} 
& 2. Tenaga Kerja & $12,647,350$ & $8,853,100$ & $11,275,200$ \\
\hline & 3. Pupuk & $16,663,800$ & $17,697,350$ & $15,280,938$ \\
\hline & 4. Pestisida & $8,863,050$ & $8,007,750$ & $8,135,400$ \\
\hline & 5. Sewa Lahan & $2,500,000$ & $2,500,000$ & $2,500,000$ \\
\hline & 6. Penyusutan Alat & 77,700 & 77,700 & 77,700 \\
\hline & TOTAL BIAYA PRODUKSI & $\mathbf{4 6 , 0 2 6 , 9 0 0}$ & $\mathbf{4 2 , 4 1 0 , 9 0 0}$ & $\mathbf{4 2 , 5 4 4 , 2 3 8}$ \\
\hline B & Biaya Pemasaran & $1,800,000$ & & $1,800,000$ \\
\hline & 1. Pengangkutan & $2,500,000$ & $2,300,000$ & $1,800,000$ \\
\hline & 2. Penanganan & $1,500,000$ & $1,500,000$ & $2,500,000$ \\
\hline & 3. Resiko & $5,800,000$ & & $1,500,000$ \\
\hline & TOTAL BIAYA & $5,600,000$ & $5,800,000$ \\
\hline & PEMASARAN & $\mathbf{5 1 , 8 2 6 , 9 0 0}$ & $\mathbf{4 8 , 0 1 0 , 9 0 0}$ & $\mathbf{4 8 , 3 4 4 , 2 3 8}$ \\
\hline & BIAYA TOTAL & $\mathbf{1 0 6 , 4 3 6 , 6 0 0}$ & $\mathbf{9 5 , 3 6 0 , 0 0 0}$ & $\mathbf{1 0 2 , 6 8 0 , 0 0 0}$ \\
\hline C & Penerimaan & $\mathbf{5 4 , 6 0 9 , 7 0 0}$ & $\mathbf{4 7 , 3 4 9 , 1 0 0}$ & $\mathbf{5 4 , 3 3 5 , 7 6 2}$ \\
\hline D & Pendapatan & & &
\end{tabular}

Sumber : diolah dari data primer

Dari tabel tersebut diketahui bahwa secara ekonomik pendapatan yang didapat rata-rata per hektar adalah sebesar 54.609 juta untuk daerah Poncokusumo, 47.349 juta untuk daerah Nongkojajar dan 54.335 juta untuk daerah Batu. Hal ini menunjukkan bahwa usahatani apel baik yang berasal dari Poncokusumo, Nongkojajar maupun batu secara ekonomik menguntungkan bagi para petani sehingga usahatani tersebut layak untuk diusahakan.

Hasil penelitian menunjukkan bahwa baik pendapatan financial maupun pendapatan ekonomik per hektar mempunyai nilai positif. Ini berarti bahwa untuk usahatani apel di Jawa Timur masih layak untuk diusahakan ataupun dibudidayakan. Tingginya pendapatan financial daripada pendapatan ekonomik dikarenakan harga yang berlaku di pasar local masih lebih tinggi dari harga yang seharusnya yaitu Rp. 8.000/kg. Disamping itu biaya biaya yang dikeluarkan untuk perhitungan secara ekonomik lebih kecil dibandingkan dengan biaya yang dikeluarkan secara financial, artinya harga yang berlaku untuk usahatani apel adalah harga tanpa subsidi sehingga secara financial harganya lebih besar daripada secara ekonomik.

\section{Analisis Keunggulan Komparatif dan}

\section{Kompetitif Usahatani Apel di Jawa Timur}

\section{Analisis keunggulan komparatif}

Keunggulan komparatif digunakan untuk menganalisa tingkat efisiensi ekonomik penggunaan sumberdaya domestic dari komoditas apel dalam upaya menghemat /menambah devisa melalui pengurangan impor dan menambah pangsa pasar. Tingkat keunggulan komparatif ini ditunjukkan oleh nilai DRCR (Domestic Resource Cost ratio), yaitu perbandingan antara faktor domestic 
dengan hasil pengurangan dari harga bayangan Nilai Tengah Rupiah penerimaan dengan input tradable.

(NTR) (Pada saat penelitian nilai tukar

Keunggulan komparatif dihitung rupiah Rp12.972 per US \$). Oleh karena berdasarkan harga bayangannya. Suatu itu, secara ekonomis dapat dikatakan komoditas dikatakan mempunyai bahwa komoditas tersebut apabila keunggulan komparatif jika nilai koefisien diusahakan secara efisien dalam DRCR lebih kecil dari satu. Nilai tersebut memanfaatkan sumbedaya domestik. menunjukkan bahwa DRCR dari Hasil analisa keunggulan komparatif komoditas tersebut yang dihitung usahatani apel dapat dilihat pada tabel 3 di berdasarkan nilai sosial lebih kecil dari bawah ini:

Tabel 3. Hasil Analisa DRCR Usahatani Apel per hektar di Poncokusumo, Nongkojajar, dan Batu Jawa Timur

\begin{tabular}{|l|r|r|r|}
\hline \multicolumn{1}{|c|}{ Uraian } & \multicolumn{1}{c|}{ Poncokusumo } & \multicolumn{1}{c|}{ Nongkojajar } & \multicolumn{1}{c|}{ Batu } \\
\hline Faktor Domestik (Rp) & 51.025 .050 & 47.030 .800 & 49.652 .900 \\
\hline Input Tradable (Rp) & 30.801 .850 & 30.980 .100 & 28.691 .338 \\
\hline Penerimaan (Rp) & 106.436 .600 & 95.360 .000 & 102.680 .000 \\
\hline DRCR (\%) & 0,67 & 0,73 & 0,67 \\
\hline
\end{tabular}

Sumber : diolah dari data primer

Tabel 3 menunjukkan bahwa nilai DRCR < 1 pada semua lokasi penelitian yaitu Poncokusumo sebesar 0,67\%, Nongkojajar 0,73\%, Batu 0,67\%. Hal ini berarti bahwa usahatani apel tersebut memiliki keunggulan komparatif. Keunggulan komparatif yang dimiliki oleh Jawa Timur pada usahatani apel diantaranya adalah rendahnya biaya input domestik. Rata-rata nilai DRCR pada komoditas apel di Jawa Timur sebesar $0,69 \%$ yang berarti setiap penggunaan biaya sebesar 69\% akan memberikan keuntungan secara ekonomik sebesar 31\% dari total penerimaan. Dengan demikian semakin kecil nilai DRCR maka keuntungan yang diperoleh akan semakin besar dan juga efisien dalam penggunaan sumberdaya domestik. Hal ini dikarenakan untuk menghasilkan satu satuan devisa (satu dollar) diperlukan pengorbanan devisa sebesar 0,69 dolar sumberdaya.

\section{Analisa keunggulan kompetitif}

Keunggulan kompetitif digunakan untuk menganalisa tingkat efisiensi finansial. Tingkat keunggulan kompetitif ini ditunjukkan oleh nilai PCR (profit cost ratio), yaitu perbandingan antara faktor 
domestic dengan nilai pengurangan dari penerimaan dan input tradable. PCR memainkan fungsi yang sama seperti DRCR, hanya berbeda dalam dasar penilaian harga. PCR dinilai dalam harga privat (financial).
Suatu komoditas memiliki keunggulan kompetitif jika memiliki nilai PCR lebih kecil dari satu, begitupun sebaliknya. Hasil analisa keunggulan kompetitif komoditas apel bisa dilihat pada table 4. di bawah ini:

Tabel 4. Hasil analisa PCR Usahatani Apel per hektar di Poncokusumo, Nongkojajar, dan Batu Jawa Timur

\begin{tabular}{|l|r|r|r|}
\hline \multicolumn{1}{|c|}{ Uraian } & \multicolumn{1}{c|}{ Poncokusumo } & \multicolumn{1}{c|}{ Nongkojajar } & \multicolumn{1}{c|}{ Batu } \\
\hline Faktor Domestik (Rp) & 38.839 .300 & 39.845 .300 & 32.466 .075 \\
\hline Input Tradable (Rp) & 33.500 .600 & 33.678 .600 & 32.716 .593 \\
\hline Penerimaan (Rp) & 115.066 .600 & 102.400 .00 & 112.800 .000 \\
\hline PCR (\%) & 0,48 & 0,59 & 0,41 \\
\hline
\end{tabular}

Sumber : diolah dari data primer

Dari hasil analisa bisa terlihat bahwa nilai PCR pada usahatani apel baik di Poncokusumo yaitu sebesar $0,48 \%$, Nongkojajar sebesar $0,59 \%$ dan Batu sebesar $0,41 \%$ hal ini berarti bahwa usahatani apel tersebut memiliki keunggulan kompetitif terhadap produk apel dari Negara lain atau dengan kata lain usahatani apel di Jawa Timur secara finansial layak untuk diusahakan atau dibudidayakan.

\section{Policy Analisys Matrik (PAM)}

Adanya distorsi pemerintah dan juga kegagalan pasar merupakan efek dari divergensi yaitu perbedaan antara harga aktual dengan harga sosial. Matrik PAM ini disusun berdasarkan modal dan biaya pemasaran serta harga output telah dipisahkan dalam komponen tradable dan domestik. Matrik PAM dapat dilihat pada tabel 5.

Tabel 5. PAM untuk Usahatani Apel

\begin{tabular}{|l|r|r|r|c|}
\hline & Penerimaan & Input & \multicolumn{1}{c|}{ Faktor } & profit \\
\hline & & Tradable & Domestik & \\
\hline PONCOKUSUMO & & & & \\
\hline Privat & $115,066,600$ & $33,500,600$ & $38,839,300$ & $42,726,700$ \\
\hline Sosial & $106,436,600$ & $30,801,850$ & $51,025,050$ & $24,609,700$ \\
\hline Divergensi & $8,630,000$ & $2,698,750$ & $-12,185,750$ & $18,117,000$ \\
\hline & & & & \\
\hline
\end{tabular}




\begin{tabular}{|l|r|r|r|r|} 
NONGKOJAJAR & & & \\
\hline Privat & $102,400,000$ & $33,678,600$ & $39,845,300$ & $28,876,100$ \\
\hline Sosial & $95,360,000$ & $30,980,000$ & $47,039,800$ & $17,340,200$ \\
\hline Divergensi & $7,040,000$ & $2,698,600$ & $-7,194,500$ & $11,535,900$ \\
\hline BATU & & & & \\
\hline Privat & $112,800,000$ & $32,716,593$ & $32,466,075$ & $47,617,332$ \\
\hline Sosial & $102,680,000$ & $28,691,338$ & $49,030,800$ & $24,957,862$ \\
\hline Divergensi & $10,120,000$ & $4,025,255$ & $-16,564,725$ & $22,659,470$ \\
\hline
\end{tabular}

Sumber: diolah dari data primer

Divergensi pada harga input (NPCI), koefisien proteksi efektif atau tradable menyebabkan biaya input Effectif Protection Coeficient (EPC) dan tradable berdasarkan harga privat (B) koefisien profitabilitas atau Profitability berbeda dengan biaya sosialnya $(\mathrm{F})$, serta terjadinya transfer input tradable $(\mathrm{J})$. dari hasil analisa PAM diperoleh nilai transfer input tradable sebesar 2.698.750 Coeficient (PC).

Kebijakan pemerintah terhadap komoditas apel dapat berupa kebijakan (Poncokusumo), 2.698.600 (Nongkojajar) terhadap output maupun input. Nilai koefisien Output Nominal (NPCO) adalah dan 4.025.255 (Batu). Hasil nilai transfer sebesar $\quad 1,08 \%$ untuk wilayah input tradable semuanya positif artinya Poncokusumo, 1,07\% wilayah divergensi ini disebabkan oleh tidak Nongkojajar dan 1,09\% wilayah Batu, adanya subsidi terhadap input tradable. artinya pemerintah melakukan transfer Perbedaan harga yang terjadi disebabkan oleh tingginya harga input tradable seperti pupuk, sehingga dalam hal ini petani sedikit rugi.

Kebijakan pemerintah dalam matrik PAM adalah Transfer Output (OT), Transfer Input (IT), Transfer Faktor (FT), dan Transfer Bersih (NT). Ukuran relative ditunjukkan oleh analisis koefisien proteksi output nominal atau Nominal Protection Coeficient on Output (NPCO), koefisien proteksi input nominal atau Nominal Protection Coeficient on Input output kepada petani apel sebesar 8.630.000/produksi di wilayah Poncokusumo, 7.040.000/produksi di wilayah Nongkojajar dan 10.120.000/produksi di wilayah Batu pada usahatani apel.

Nilai Koefisien Proteksi Input Nominal $(\mathrm{NPCI})>1$, yang berarti bahwa pemerintah melakukan proteksi terhadap produsen input tradable. Selain itu juga nilai EPC > 1, yang berarti bahwa secara umum petani diuntungkan dengan adanya intenvensi pemerintah. Keuntungan secara 
individual yang diterima petani lebih maupun penurunan harga output apel. besar dari keuntungan social yang Analisis sensitivitas dilakukan dengan diterima konsumen. meningkatkan asumsi kenaikan harga bibit sebesar $10 \%$, kenaikan upah tenaga kerja

Analisis Sensitivitas Usahatani Apel di $10 \%$, kenaikan harga pupuk sebesar $10 \%$, Jawa Timur

Analisis sensitivitas merupakan dan penurunan harga output sebesar $10 \%$ analisis untuk mengetahui kepekaan untuk semua tempat tujuan perdagangan penguasaan komoditas apel, jika terjadi perubahan harga baik input sumberdaya baik di Jawa Timur maupun luar Jawa Timur. Hasil analisa sensitivitas dapat dilihat pada tabel 6. di bawah ini:

Tabel 6. Hasil Analisa Sensitivitas Kenaikan Harga Input (bibit, tenaga kerja dan pupuk) dan Penurunan Harga Output di Jawa Timur

\begin{tabular}{|r|l|l|l|l|l|l|r|}
\hline \multirow{2}{*}{ No } & \multicolumn{2}{|c|}{ Kondisi } & \multicolumn{3}{c|}{ Nilai DRCR } & \multicolumn{3}{c|}{ Nilai PCR } \\
\cline { 3 - 8 } & & $\begin{array}{c}\text { Poncoku- } \\
\text { sumo }\end{array}$ & $\begin{array}{c}\text { Nongko- } \\
\text { jajar }\end{array}$ & Batu & $\begin{array}{c}\text { Poncoku- } \\
\text { sumo }\end{array}$ & $\begin{array}{c}\text { Nongko- } \\
\text { jajar }\end{array}$ & Batu \\
\hline 1 & Bibit naik 10\% & 0.68 & 0.74 & 0.68 & 0.48 & 0.58 & 0.41 \\
\hline 2 & Pupuk Naik 10\% & 0.69 & 0.75 & 0.69 & 0.49 & 0.6 & 0.42 \\
\hline 3 & TK naik 10\% & 0.69 & 0.74 & 0.68 & 0.5 & 0.6 & 0.42 \\
\hline 4 & Output Turun 10\% & 0.78 & 0.73 & 0.78 & 0.56 & 0.68 & 0.47 \\
\hline
\end{tabular}

Sumber: diolah dari data primer

Analisis sensitivitas dengan

kenaikan harga bibit sebesar 10\% akan berpengaruh terhadap total biaya yang akan dikeluarkan dalam usahatani apel. perubahan harga apel tidak terlalu berpengaruh terhadap keunggulan komparatif usahatani apel di Jawa Timur.

Dengan adanya kenaikan total biaya maka Dari hasil analisa sebelumnya akan mempengaruhi perubahan dalam terlihat bahwa biaya yang dikeluarkan untuk tenaga kerja memiliki presentase keunggulan komparatif usahatani apel tertinggi dibandingkan dengan biayatersebut. Hasil analisis menunjukkan bahwa dengan naiknya harga bibit akan berpengaruh dengan nilai DRCR, akan tetapi nilai DRCR masih berada di bawah 1, yaitu 0,68 untuk wilayah Poncokusumo, biaya yang lainnya. Dengan adanya kenaikan upah tenaga kerja yang naik dari Rp.15.000 menjadi Rp.16.500 tiap satuan HKP, maka terjadi kenaikan nilai DRCR menjadi 0,69 untuk wilayah 0,74 wilayah Nongkojajar dan 0,68 Poncokusumo, 0,74 wilayah Nongkojajar wilayah Batu. Dengan demikian adanya dan 0,68 wilayah batu. Hal ini 
menunjukkan bahwa pemakaian sumberdaya domestic dikatakan efisien atau memiliki keunggulan komparatif. Begitu juga dengan kenaikan harga pupuk sebesar $10 \%$ juga mengakibatkan kenaikan nilai DRCR menjadi 0,69 untuk wilayah Poncokusumo, 0,75 wilayah Nongkojajar dan 0,69 wilayah Batu. Hal ini menunjukkan dengan adanya kenaikan harga pupuk, usahatani apel masih memiliki keunggulan komparatif.

Analisis sensitivitas yang terakhir adalah penurunan harga output apel sebesar 10\%. Harga yang semua Rp.8.000 turun menjadi Rp.7.200. Dengan adanya penurunan harga tersebut juga menaikkan nilai DRCR nya, akan tetapi nilai DRCR nya masih berada di bawah 1 sehingga usahatani apel masih memiliki keunggulan komparatif. Dengan menlihat semua nilai DRCR tersebut, dapat dilihat bahwa adanya penurunan harga output memiliki pengaruh yang paling tinggi terhadap perubahan nilai keunggulan komparatif dibandingkan dengan kenaikan harga bibit, upah tenaga kerja maupun harga pupuk.

\section{KESIMPULAN DAN SARAN}

\section{Kesimpulan}

1. Hasil analisa di dapat bahwa rata-rata pendapatan secara financial sebesar
Rp.54.740.044 dan rata-rata pendapatan secara ekonomik sebesar Rp.52.098.187. Dengan demikian baik secara ekonomik maupun financial, pendapatan komoditass apel di Jawa Timur bernilai positif. Hal ini berarti bahwa usahatani apel di Jawa Timur secara ekonomi dan financial menguntungkan dan layak untuk dibudidayakan.

2. Analisa rata-rata nilai DRCR sebesar 0,69 dan nilai rata-rata PCR sebesar 0,49. Dengan demikian analisa keunggulan kompetitif lebih besar dari analisa keunggulan komparatif, sehingga usahatani apel Jawa Timur masih mempunyai daya saing baik di pasar dalam negeri mapun pasar luar negeri.

3. Analisis sensitivitas dengan naiknya harga bibit sebesar 10\%, kenaikan upah tenaga kerja sebesar $10 \%$, harga pupuk sebesar $10 \%$ dan penurunan output sebesar $10 \%$ menyebabkan perubahan DRCR dan PCR, akan tetapi nilainya masih dibawah satu. Hal ini berarti bahwa usahatani apel di Jawa Timur masih layak untuk diusahakan. 


\section{Saran}

1. Dengan adanya keunggulan komparatif dan kompetitif dalam penguasaan komoditas apel di Jawa Timur, maka petani masih perlu mengembangkan dan meningkatkan produksi apel untuk memenuhi permintaan masyarakat dan bisa menghemat devisa serta meningkatkan pendapatan petani baik secara ekonomik maupun financial.

2. Kebijakan pemeerintah dalam meningkatkan distribusi pendapatan dapat dilakukan dengan memperbaiki struktur pasar, sehingga ada pemerataan pendapatan diantara pelaku ekonomi yang menjamin keamanan pangan serta pengembangan usahatani yang nantinya akan menimbulkan kualitas apel dan memenuhi standart mutu ekspor.

3. Pemerintah hendaknya terus mendukung dalam pengembangan dan peningkatan produktifitas apel karena dapat meningkatkan pendapatan dan tingkat kesejahteraan petani apel.

\section{DAFTAR PUSTAKA}

Agustina, Titin. (2008). Analisa Daya Saing Apel Tropis di Kota Batu. Fakultas Pertanian Universitas Jember. Jurnal Sosial Ekonomi Pertanian Vol.2. Nomor 2. Juli.
Andriyani, Retno Dwi. (2010). Keunggulan Komparatif dan Kompetitif Usahatani Apel di Kecamatan Poncokusumo Kabupaten Malang. Jurnal AGRISE Volume X. Nomor 1. Januari. ISSN : $1412-1425$

Daniel, M. (2003). Metode Penelitian Sosial Ekonomi. Jakarta: Penerbit Bumi Aksara.

Downey dan Ericson. (1992). Manajemen Agribisnis.Edisi ke-2. Cetakan ke-3. Ganda S dan A Sirait, Penerjemah. Jakarta:Erlangga.

Haryadi, (1989). Dasar-dasar Holtikultura. Jurusan Budidaya Pertanian. Fakultas Pertanian. Institut Pertanian Bogor.

Kusumo. (2001). Budidaya Apel (Malus syvestriss). Lembaga Penelitian Hortikultura. Direktorat Pertanian.

Nugroho, (2001). Analisa Pendapatan Usahatani Apel Malang. Jurusan Sosial Ekonomi Pertanian. Fakultas Pertanian. Institut Pertanian Bogor.

Pearson, Scott. Dkk. (2005). Aplikasi Policy Analysis Matrix Pada pertanian Indonesia. Jakarta: Yayasan Obor Indonesia.

Rahardi, F. dkk. (2002). Agribisnis Tanaman Buah. Jakarta: Penebar Swadaya.

Sudaryanto dkk. (1992). Penelitian Agribisnis Komoditas Hortikultura. Pusat Penelitian Sosial Ekonomi Pertanian. Bogor.

Suhariyanto dkk. (2011). Balai Penelitian Tanaman Jeruk dan Buah-buahan Sub Tropis. Pusat penelitian Tanah. Universitas Brawijaya. Malang. 